TINATIN GOGNADZE, SHORENA TSIKLAURI,

GHANATE RAHUL KUMAR, RAGINI, NIKHIL KUMAR

\title{
TREATMENT AND PREVENTION OF POST-CHEMOTHERAPY THROAT DRYING IN ONCOLOGY PATIENTS WITH NATURAL DRUG - ISLA MINT
}

European University, Tbilisi, Georgia

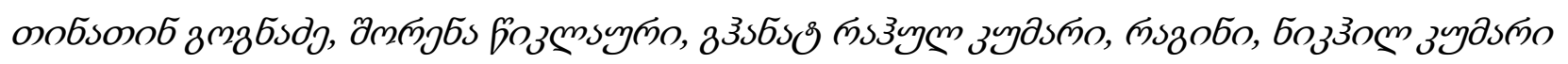

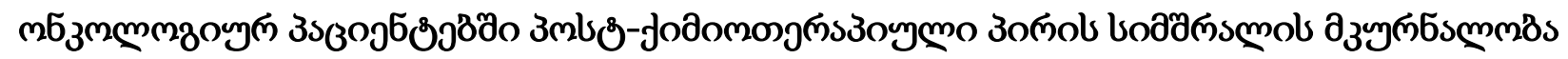

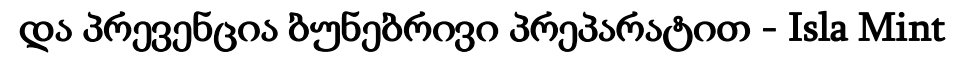

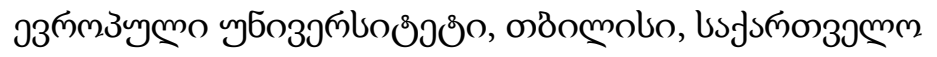

\section{mg8oyag}

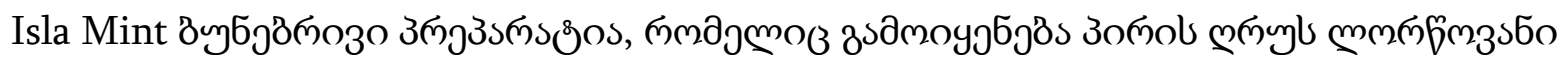

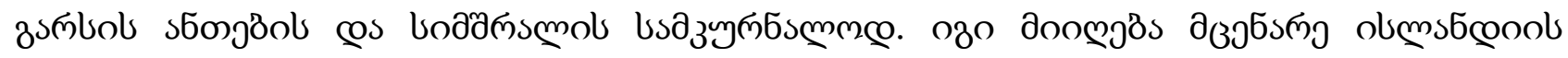

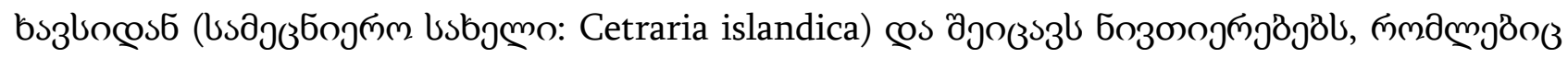

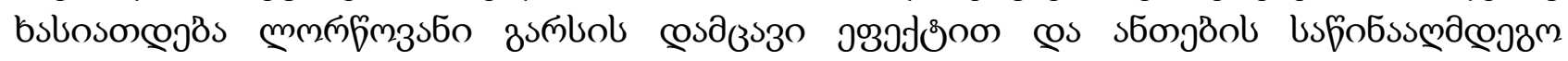

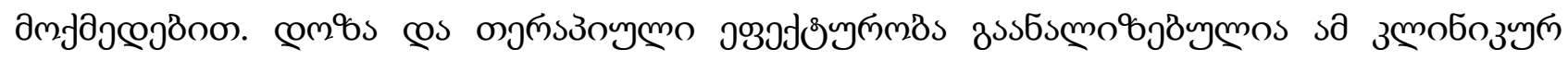

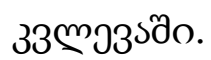

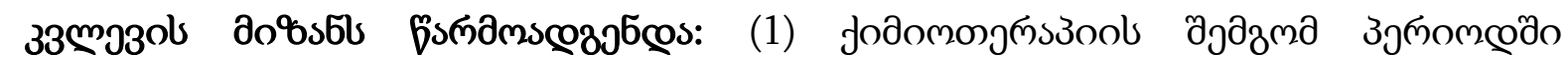

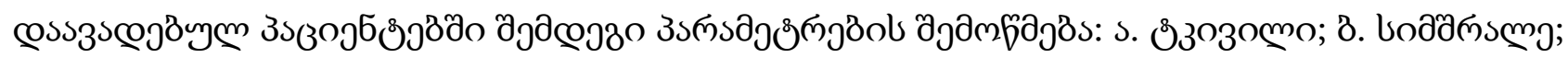

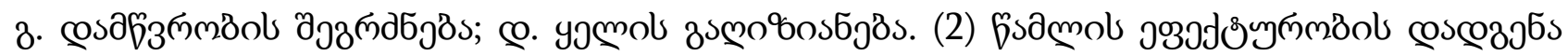

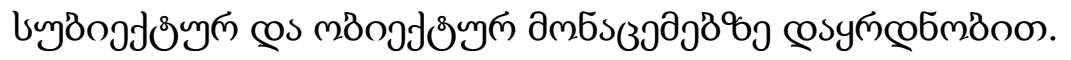

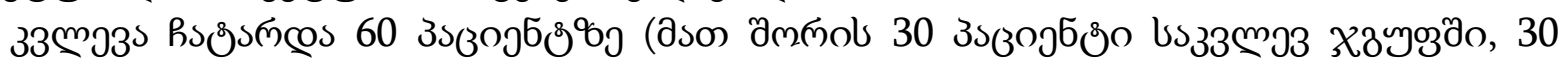

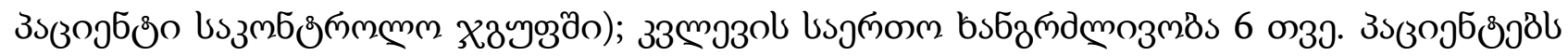

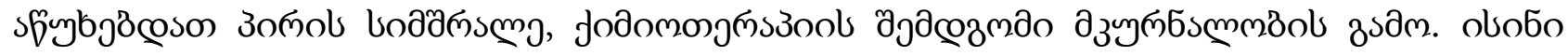

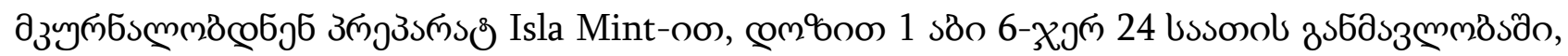

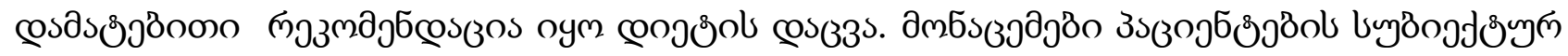

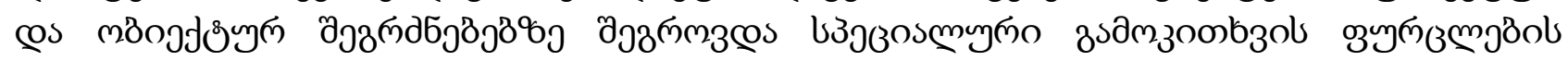

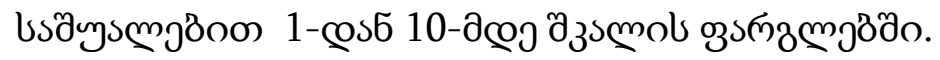

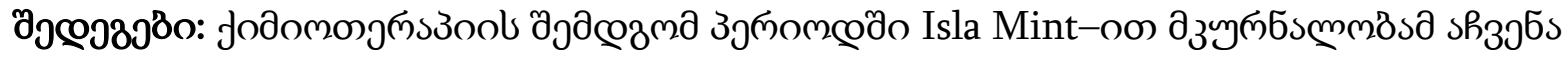

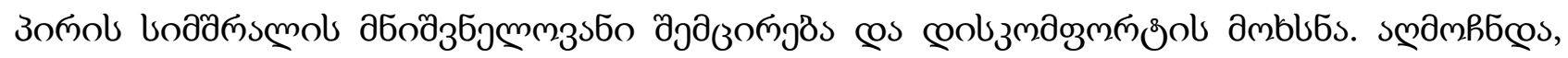

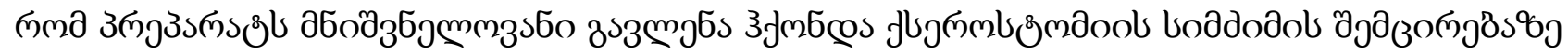

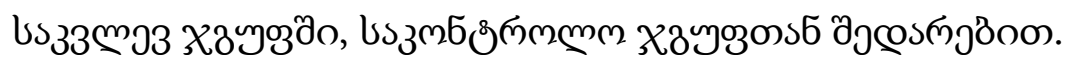

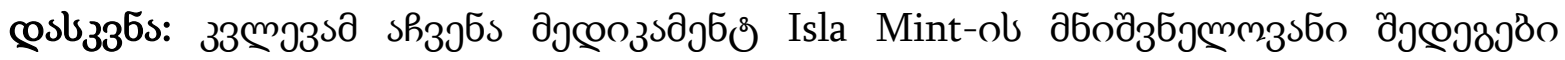
мбзммпзолп зьзојб

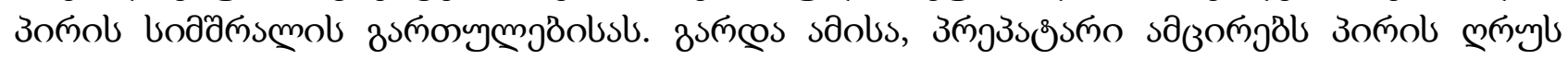

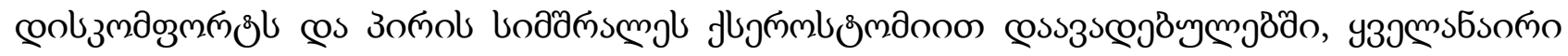

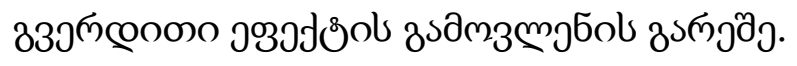

Introduction. Cancer is one of the leading causes of morbidity and mortality worldwide. Every year, approximately 38 million people die with non-communicable diseases, in which over 8 million deaths occur because of cancer. Though, remarkable evolution in knowledge of cancer has led to progress in cancer treatment, early diagnosis, and treatment. But, the scenario related to the fatality of cancer, has not changed.

The diseases which are secondary to cancer impose other challenges in terms of prevention, detection, and treatment. These can be categorized as one which is directly related to cancer patho-physiology, and second which is the consequence of radiotherapy and chemotherapy treatment of cancer. The first category of diseases shows probability to occur and has its specific treatment protocol, but the morbidities arise as the side effects of cancer treatment, 
are inevitable. The adverse effects include oral mucositis, gastrointestinal toxicity, hepatotoxicity, nephrotoxicity, hematopoietic system injury, cardiotoxicity, and neurotoxicity which in turn, limit the clinical use of therapy, and may lead to therapy discontinuation (Shapiro, 2016; Turcotte et al., 2017).

Xerostomia is one of the most common complications in cancer patients. This is related to the sensation of dryness of mouth, which is associated with the hypo salivation; leading to oral mucositis. Since the mucosal cells have high turnover rate, and are also sensitive to the chemotherapeutic agents which are highly absorbable by these cells, which lead to the damage and death to these cells and tissues. Mucositis is an acute injury to the oral mucosa because of reduced salivary secretion and dryness of mouth which can become infected by a variety of bacteria; sepsis presents a life-threatening situation to the patient. Chemotherapy induces damage to the salivary glands, but the physiological basis of xerostomia and mucositis is not completely understood. Although, researches support the link among these pathological changes but, more clinical evidence-based knowledge is required to solve the controversies among the studies which had found correlation between severity and recovery.

Several studies have been performed on different natural product for preventing or reducing chemotherapy induced xerostomia. Physiological effects of these natural medicines are mostly associated to its chemical compositions such as polyphenols, carotenoids, triterpenes and essential oils which show anti-inflammatory, antitumorigenic, antioxidant, and antimicrobial activities. Isla Mint is a natural drug of Icelandic moss based pastilles. This drug has protective antimicrobial, anti-inflammatory and immune-modulatory effects which envelop and moisturize the mucous cells. This property of this drug humidifies the respiratory mucosa and thus removes inflammation.

The therapeutic effects of a drug are considered to be beneficial to those who need it, when it has considerable therapeutic action at minimal dose with less or no side effects, and if any adverse reactions occur; can be controlled.

The aim of this study is to check the effectiveness of Isla mint drug in the treatment of dryness of mouth, caused by the cancer drugs. The objective of this research is to determine prevention of xerostomia during chemotherapy treatment, and to set its rate based on subjective and objective data.

Methodology. This study has been performed in accordance with the international research standards, and implemented with the support of Aversi clinic, Tbilisi, Georgia. The study complies all ethical rules and regulations in Georgia, and has been carried out by respecting the local culture which is consistent with legal statutes and regulations for the protection of human subjects. The cancer patients, who were diagnosed with xerostomia by histological and clinical evaluation, were eligible for this drug trial.

The total 60 patients are included in this study; duration of study - 6 months. These patients are divided into two groups i.e. one study group and second control group, consisting of equal number of participants. The patients, who were taking the chemotherapy treatment, were assessed and evaluated for taste sensation by otolaryngologist before determining the subjective and objective data; subjective sensation by using scale from numbers 1 to 10 with an interpretation of reduction in discomfort as the rating on the scale increases. The objective data was collected on the basis of a feedback form that contained the questions of general complaints like Pain, Burning sensation, dryness, and irritation. These questions were provided/given with four options, i.e. No, seldom, often, and always. 
The strategy to carry out the study was clearly explained, and consists of following steps:

- Both groups of patients are given oral recommendations of drug with complete explanation of the procedure of rehabilitation during the drug trial.

- The study group is given additional recommendations and information about natural quality of drug Isla Mint and its possible physiological effects.

- To collect the subjective and objective data, the frequency of visits to the Otolaryngologist were kept to 2 to 3 times per week.

Results. In accordance with the requirement of the study, all participants were observed. The 30 patients were selected for the data collection and follow the special recommendations for oral care, which were:

- Balanced diet;

- Restrain the crude food to avoid further damage to the oral mucosa;

- Suction of mouth 2 times per day.

The patients were prescribed 1 tablet of drug Isla Mint 6 times per day for 10 days. The oral mucosa was examined by pharyngoscope, and visual assessment were made by comparing pale pink color of healthy mucosa with cancer patient's mucosa having xerostomia. The participants repeated the regular visits, an objective data was collected on the basis of clinical examination; subjective feelings had not changed, or were recorded slightly worse. The graph was plotted, based on the collected objective data:

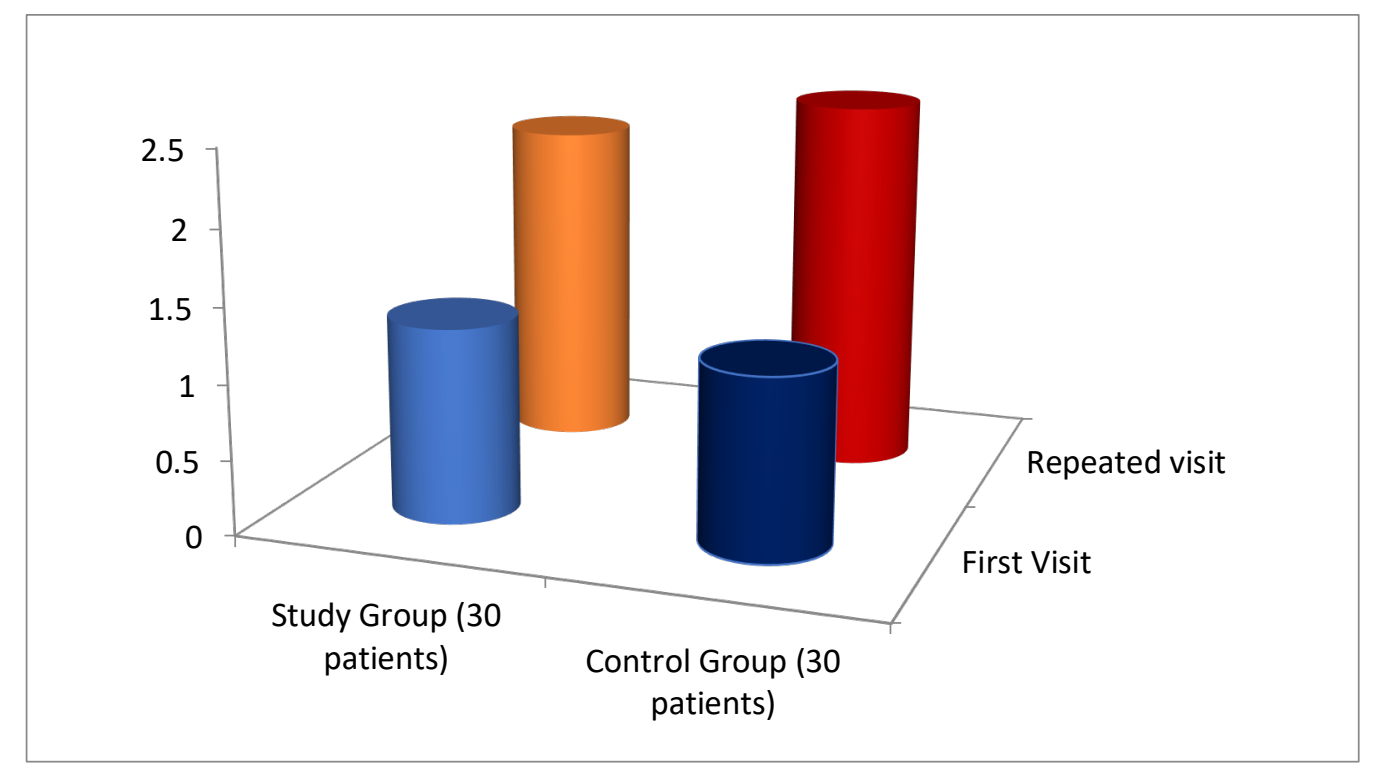

The results on the basis of feedback form are as follows:

Mixed

\begin{tabular}{|c|c|c|c|c|c|c|c|}
\hline Symptom & Occurrence & Control (30) & $\%$ & Isla Mint (20) & $\%$ & Variance & $\begin{array}{l}\text { Remarks - with Isla } \\
\text { Mint vs normal }\end{array}$ \\
\hline PAIN & NO & 12 & $40 \%$ & 22 & 73\% & $33 \%$ & \multirow{3}{*}{$\begin{array}{l}\text { Increase in no. } \\
\text { occurrence of " NO } \\
\text { pain" }\end{array}$} \\
\hline PAIN & SELDOM & 18 & $60 \%$ & 7 & $23 \%$ & $-37 \%$ & \\
\hline PAIN & Often & 0 & $0 \%$ & 1 & $3 \%$ & $3 \%$ & \\
\hline BURNING & NO & 16 & $53 \%$ & 24 & $80 \%$ & $27 \%$ & \multirow{2}{*}{$\begin{array}{l}\text { Increase in no. } \\
\text { occurrence of " NO } \\
\text { burning sensation" }\end{array}$} \\
\hline BURNING & SELDOM & 14 & $47 \%$ & 6 & $20 \%$ & $-27 \%$ & \\
\hline DRYNESS & NO & 6 & $20 \%$ & 17 & $57 \%$ & $37 \%$ & \multirow{3}{*}{$\begin{array}{l}\text { Increase in no. } \\
\text { occurrence of " NO } \\
\text { dryness sensation" }\end{array}$} \\
\hline DRYNESS & SELDOM & 22 & $73 \%$ & 13 & $43 \%$ & $-30 \%$ & \\
\hline DRYNESS & OFTEN & 2 & $7 \%$ & 0 & $0 \%$ & $-7 \%$ & \\
\hline IRRITAION & $\mathrm{NO}$ & 23 & $77 \%$ & 23 & $77 \%$ & $0 \%$ & \multirow{2}{*}{$\begin{array}{l}\text { No difference in } \\
\text { irritation occurrence }\end{array}$} \\
\hline IRRITAION & SELDOM & 7 & $23 \%$ & 7 & $23 \%$ & $0 \%$ & \\
\hline
\end{tabular}


Results Based on the gender discrimination:

Women

\begin{tabular}{|c|c|c|c|c|c|c|c|}
\hline Symptom & Occurrence & Control (20) & $\%$ & Isla Mint (22) & $\%$ & Variance & $\begin{array}{l}\text { Remarks - with Isla } \\
\text { Mint vs normal }\end{array}$ \\
\hline PAIN & $\mathrm{NO}$ & 8 & $40 \%$ & 15 & $68 \%$ & $28 \%$ & \multirow{3}{*}{$\begin{array}{l}\text { Increase in no. } \\
\text { occurrence of " } \mathrm{NO} \\
\text { pain" }\end{array}$} \\
\hline PAIN & SELDOM & 12 & $60 \%$ & 6 & $27 \%$ & $-33 \%$ & \\
\hline PAIN & Often & 0 & $0 \%$ & 1 & $5 \%$ & $5 \%$ & \\
\hline BURNING & $\mathrm{NO}$ & 11 & $55 \%$ & 17 & $77 \%$ & $22 \%$ & \multirow{2}{*}{$\begin{array}{l}\text { Increase in no. } \\
\text { occurrence of " NO } \\
\text { burning sensation" }\end{array}$} \\
\hline BURNING & SELDOM & 9 & $45 \%$ & 5 & $23 \%$ & $-22 \%$ & \\
\hline DRYNESS & $\mathrm{NO}$ & 4 & $20 \%$ & 12 & $55 \%$ & $35 \%$ & \multirow{3}{*}{$\begin{array}{l}\text { Increase in no. } \\
\text { occurrence of " NO } \\
\text { dryness sensation" }\end{array}$} \\
\hline DRYNESS & SELDOM & 14 & $70 \%$ & 10 & $45 \%$ & $-25 \%$ & \\
\hline DRYNESS & OFTEN & 2 & $10 \%$ & 0 & $0 \%$ & $-10 \%$ & \\
\hline IRRITAION & $\mathrm{NO}$ & 16 & $80 \%$ & 15 & $68 \%$ & $-12 \%$ & \multirow{2}{*}{$\begin{array}{l}\text { Increase in no. } \\
\text { occurrence of " NO } \\
\text { irritation sensation" }\end{array}$} \\
\hline IRRITAION & SELDOM & 4 & $20 \%$ & 7 & $32 \%$ & $12 \%$ & \\
\hline
\end{tabular}

Men

\begin{tabular}{|c|c|c|c|c|c|c|c|}
\hline Symptom & Occurrence & Control (10) & $\%$ & Isla Mint (8) & $\%$ & Variance & $\begin{array}{l}\text { Remarks - with Isla } \\
\text { Mint vs normal }\end{array}$ \\
\hline PAIN & $\mathrm{NO}$ & 4 & $40 \%$ & 7 & $88 \%$ & $48 \%$ & \multirow{2}{*}{$\begin{array}{l}\text { Increase in no. } \\
\text { occurrence of " NO } \\
\text { "pain" }\end{array}$} \\
\hline PAIN & SELDOM & 6 & $60 \%$ & 1 & $13 \%$ & $-48 \%$ & \\
\hline BURNING & $\mathrm{NO}$ & 5 & $50 \%$ & 7 & $88 \%$ & $38 \%$ & \multirow{2}{*}{$\begin{array}{l}\text { Increase in no. } \\
\text { occurrence of " NO } \\
\text { burning sensation" }\end{array}$} \\
\hline BURNING & SELDOM & 5 & $50 \%$ & 1 & $13 \%$ & $-38 \%$ & \\
\hline DRYNESS & $\mathrm{NO}$ & 2 & $20 \%$ & 5 & $63 \%$ & $43 \%$ & \multirow{2}{*}{$\begin{array}{l}\text { Increase in no. } \\
\text { occurrence of " NO } \\
\text { dryness sensation" }\end{array}$} \\
\hline DRYNESS & SELDOM & 8 & $80 \%$ & 3 & $38 \%$ & $-43 \%$ & \\
\hline IRRITAION & $\mathrm{NO}$ & 7 & $70 \%$ & 8 & $100 \%$ & $30 \%$ & \multirow{2}{*}{$\begin{array}{l}\text { Increase in no. } \\
\text { occurrence of " NO } \\
\text { irritation sensation" }\end{array}$} \\
\hline IRRITAION & SELDOM & 3 & $30 \%$ & 0 & $0 \%$ & $-30 \%$ & \\
\hline
\end{tabular}

Discussion. Saliva, which consists of water (99\%) and many digestive components like electrolytes, immunoglobulin, enzymes, mucins etc., also serves important functions in maintaining the health of oral cavity, speech, and ingestion. Dryness of mouth a subjective feeling is usually associated with insufficient saliva secretion which is caused either due to blockage of salivary duct or due to the damage of salivary gland and surrounding mucous cells and tissues. This pathological scenario presents a potential risk for developing secondary oral infections and affects the quality of life. Cancer therapies including chemotherapy or radiotherapy alone, or as combination therapy, induce salivary gland dysfunction which leads into xerostomia, generally within a week of initiation of anti-cancer therapies. The present treatment of xerostomia can be divided into general supportive measures, salivary substitutes, and salivary stimulants. Herbal formulas have shown a significant effect on reducing the severity of dry mouth, which are divided into preventive and therapeutic categories.

Isla mint is the natural drug that is extracted from the Iceland moss (Cetraria islandica) which has been used to treat inflammation and dryness of the pharyngeal mucosa in folk medicine for many years. The lozenge is used for removal of inflammatory symptoms, and promotes moistening and repair of oral mucosa. The arena of therapeutic uses of Isla mint is extensive which includes inflammatory diseases of the throat, symptomatic therapy of dry cough in the treatment of complex and chronic bronchitis and bronchial asthma, and drying and irritation of the mucous membrane of the mouth.

Regarding the grades of subjective data for xerostomia, clinical sequence showed significant effectiveness for reducing the severity of dry mouth. However, the adverse effects like 
allergic reactions were relatively rare but, we cannot conclude that the use of herbal formula for xerostomia is safe that did not report the side effects. The clinical evidence-based documentation on adverse reactions is needed to draw conclusion on drug safety.

From the results of this study we can assume that the herbal drugs used either individually or in combination therapy with anti-cancer drugs have preventive or therapeutic effects for xerostomia in cancer patients. However, due to methodological limitations it is difficult to draw clear conclusions on the adverse effects of herbal medicine, Isla Mint.

Conclusion. At this stage, the study shows significant outcomes in oral care of oncologic patients with the use of drug Isla Mint. In addition, with other general dietary modifications, it reduces the oral discomfort and severity of dry mouth in xerostomia patients, relatively without any adverse effect. In future, extensive clinical trials are warranted to draw definitive results on the effectiveness and side effects of natural drugs.

Declaration of Conflicting Interests: The author(s) declared no potential conflicts of interest with respect to the research, authorship, and/or publication of this article.

\section{References:}

1. Aghamohamamdi, A., \& Hosseinimehr, S. J. (2016). Natural Products for Management of Oral Mucositis Induced by Radiotherapy and Chemotherapy. Integrative cancer therapies, 15(1), 60-68. https://doi.org/10.1177/1534735415596570

2. Park, B., Noh, H., \& Choi, D. J. (2018). Herbal Medicine for Xerostomia in Cancer Patients: A Systematic Review of Randomized Controlled Trials. Integrative cancer therapies, 17(2), 179-191. https://doi.org/10.1177/1534735417728336

3. Zhang, Q. Y., Wang, F. X., Jia, K. K., \& Kong, L. D. (2018). Natural Product Interventions for Chemotherapy and Radiotherapy-Induced Side Effects. Frontiers in pharmacology, 9, 1253. https://doi.org/10.3389/fphar.2018.01253

ТИНАТИН ГОГНАДЗЕ, ШОРЕНА ЦИКЛА УРИ, ГАНАТЕ РАХУЛ КУМАР, РАГИНИ, НИХИЛ КУМАР

\section{ЛЕЧЕНИЕ И ПРОФИЛАКТИКА СУХОСТИ ГОРЛА ПОСЛЕ ХИМИОТЕРАПИИ У ОНКОЛОГИЧЕСКИХ ПАЦИЕНТОВ НАТУРАЛЬНЫМ ПРЕПАРАТОМ - ISLA MINT}

Европейский университет, Тбилиси, Грузия

\section{PЕЗЮМЕ}

Isla Mint - это натуральное лекарство, которое использовалось для лечения воспалений и сухости слизистой оболочки полости рта, полученное из растения исландский мох (научное название: Cetraria islandica). Он содержит вещества, которые обладают защитным действием на слизистые оболочки и противовоспалительным действием. Доза и терапевтическая эффективность были проанализированы в этом клиническом исследовании.

Цель данного исследования - (1) проверить эффективность лекарственного средства при таких симптомах горла, как: а. Боль, б. сухость, с. ощущение жжения и d. раздражение - вызванное химиотерапией у онкологических больных, и (2) определить степень ее эффективности на основе субъективных и объективных данных.

Методы. Было проведено исследование 60 пациентов (в том числе 30 в основной группе, 30 в контрольной) при общей продолжительности исследования 6 месяцев. Эти пациенты страдают от сухости ротовой полости из-за пост химиотерапевтического лечения. Пациенты, получавшие препарат Исла Минт в дозе 1 таблетка 6 раз в течение 24 часов, с дополнительными диетическими рекомендациями. Субъективные и объективные данные были собраны по шкале, разработанной врачом, которая регистрировала субъективное ощущение дискомфорта от 1 до 10. 
Результаты: Лечение Isla Mint показало значительное уменьшение выраженности сухости во рту. Было обнаружено, что препарат оказывает значительное влияние на снижение степени выраженности ксеростомии в экспериментальной группе по сравнению с контрольной группой.

Заключение. На данном этапе исследование показывает значительные результаты в уходе за полостью рта онкологических больных с применением препарата Исла Минт. Кроме того, с другими общими диетическими модификациями он уменьшает дискомфорт во рту и тяжесть сухости во рту у пациентов с ксеростомией, относительно без каких-либо побочных эффектов. В будущем необходимы обширные клинические испытания для получения окончательных результатов об эффективности и побочных эффектах натуральных лекарств.

Ключевые слова: Isla Mint, ксеростомия, химиотерапия.

\section{TINATIN GOGNADZE, SHORENA TSIKLAURI, GHANATE RAHUL KUMAR, RAGINI, NIKHIL KUMAR \\ TREATMENT AND PREVENTION OF POST-CHEMOTHERAPY THROAT DRYING IN ONCOLOGY PATIENTS WITH NATURAL DRUG - ISLA MINT}

European University, Tbilisi, Georgia

\section{SUMMARY}

Background: Isla Mint is a natural drug, which has been used to treat the inflammation and dryness of oral mucosa, is extracted from the plant Iceland moss (Scientific name: Cetraria islandica). It contains substances that are characterized by its protective mucous membrane effects and its anti-irritant effect. The dose and therapeutic effectiveness have been analyzed in this clinical study.

The goal of this study is - (1) To check the effectiveness of drug in throat ailments like: a.Pain, b. dryness, c. burning sensation, and d. irritation - caused by the chemotherapy in cancer patients, and (2) To determine its rate of effectiveness based on the subjective and objective data.

Methods: A study of 60 patients (including 30 in the study group, 30 in the control group) has been conducted in the overall study duration of 6 months. These patients suffer from dryness of the oral cavity due to post chemotherapy treatment. The patients treated with drug Isla Mint with a dose of 1 tablet 6 times in a period of 24 hours with additional dietary recommendations. The subjective and objective data were collected on a clinician derived scale which recorded the subjective discomfort sensation from 1 to 10.

Results: The treatment with Isla Mint has shown a significant reduction in the severity of dryness of mouth. The drug was found to have a significant effect on lowering the severity of xerostomia in the intervention group compared with the control group.

Conclusion: At this stage, the study shows significant outcomes in oral care of oncologic patients with the use of drug Isla Mint. In addition, with other general dietary modifications, it reduces the oral discomfort and severity of dry mouth in xerostomia patients, relatively without any adverse effect. In future, extensive clinical trials are warranted to draw definitive results on the effectiveness and side effects of natural drugs.

Keywords: Isla Mint, xerostomia, chemotherapy 